\title{
Malgorzata Fronczek
}

University of Economics in Katowice

e-mail: malgorzata.fronczek@ue.katowice.pl

ORCID: 0000-0002-1502-1168

\section{PARTICIPATION IN GVCS AND THE SIZE OF AN ECONOMY - THE CASE OF DEVELOPED AND DEVELOPING ECONOMIES}

DOI: $10.15611 / \mathrm{pn} .2020 .4 .04$

JEL Classification: F100, F140, F150

(C) 2020 Małgorzata Fronczek

This is an open access article distributed under the Creative Commons Attribution-NonCommercial-NoDerivs license (http://creativecommons.org/licenses/by-nc-nd/3.0/)

Quote as: Fronczek, M. (2020). Participation in GVCs and the size of an economy - the case of developed and developing economies. Prace Naukowe Uniwersytetu Ekonomicznego we Wrocławiu, 64(4).

\begin{abstract}
The article aims to examine the relationship between the participation of developed and developing countries in GVCs and the size of their economies (GDP was adopted as a measure of the size of an economy). The results indicated a moderate but negative relationship between the GVC index and the GDP value, which means that larger countries were less involved in GVCs. However, the separation of developed countries from developing countries for the purpose of the analysis yielded interesting results. The calculations showed that the participation of developing countries in GVCs was on average only slightly weaker than the involvement of developed countries, but the relationship between the examined variables was only true for developed countries (the correlation coefficient indicated a moderate negative relationship). The participation of developing countries in GVCs, on the other hand, was not related to the size of their economies.
\end{abstract}

Keywords: trade in value added, globalization, international trade, global value chains, GVC.

\section{Introduction}

Economists have observed that modern globalization processes lead to the delocation of particular stages of economic processes and the relocation of some of them outside a country. This is called offshoring and research results show that it is becoming increasingly prevalent [Grossman and Helpman 2005; Grossman and Rossi-Hansberg 2008], and consequently one can talk about global value chains (GVCs) and vertical 
production specialization as well as vertical specialization in international trade, indicating the participation of particular countries in the production chain of specific goods or services. Extensive literature is available on vertical specialization in trade and its implications for international trade [Johnson, Berns, and Yi 2011; Ng 2010; Johnson and Noguera 2012b].

The concept of vertical specialization in trade was introduced by Hummels, Ishii and Yi [Hummels et al. 2001]. Since the fragmentation of production and the creation of GVCs cause that the value of final goods/services embraces both domestic and foreign value, they proposed that foreign value added contained in the exports of a given country should be a measure of its vertical specialization in trade. The results that they achieved showed that specialization is stronger in smaller countries than in larger ones. Similar studies were also carried out by R.C. Johnson and G. Noguera [Johnson and Noguera 2012a]. They used data on bilateral trade flows in 2001 for 69 countries and 18 regions. The analysis revealed that in 2001 the foreign contribution to exports was on average around $27 \%$, but the situation varied significantly between the countries under examination.

A larger foreign contribution was observed in the exports of European countries and a slightly smaller one in the exports of African states and in both Americas. In their study in 2009, Daudin, Rifflart, and Schweisguth [Daudin et al. 2011] analysed value added in trade of the countries for which data were available in the GTAP ${ }^{1}$ database for the years of 1997, 2001, 2004. They argued that the imported input of world exports was about 25\%, but it was higher in Asia (30\%) and Europe (26\%), yet lower in Africa (17\%) and both Americas (18\%). It was also higher in smaller countries than in larger ones. This pattern was also observed by Foster-McGregor and Stehrer [Foster-McGregor and Stehrer 2013]. In addition, they observed that the contribution of foreign value added in exports of the examined countries decreased during the crisis (2009), only to return to pre-crisis levels in 2009-2011. The observations were confirmed by Los, Timmer, and de Vries in the article published in 2015 [Los, Timmer, and Vries 2015].

Currently, the participation of a given country in GVCs is measured in terms of upstream and downstream participation in GVCs. The former component is the contribution of foreign value added in the exports of a given country (SFVA), while the latter is the contribution of domestic value added in the exports of other countries (SDVA). Their sum makes up the $\mathrm{GVC}^{2}$.

${ }^{1}$ GTAP (Global Trade Analysis Project), a platform facilitating cooperation between researchers and practitioners involved in research on the global economy and launched the GTAP Database. Available: https://www.gtap.agecon.purdue.edu/databases/default.asp.

2 This method was used to estimate the participation of particular countries in GVCs, e.g. UNCTAD [World Investment... 2013]. 
The literature also includes studies assessing the position of particular countries or regions in $\mathrm{GVCs}^{3}$. In 2013 and 2014 such an analysis was carried out by Banga [Banga 2013; Banga 2014], who stated that in 2009 approximately $67 \%$ of global added value was created by the developed countries that are OECD members. Developing countries definitely had a weaker participation in GVCs. The largest share of global value added created in GVCs was attributable to China, Germany, the USA (approximately 9\% each), France, Italy, Great Britain and Japan. Similar results were obtained by Amador, Cappariello and Stehrer [Amador, Cappariello and Steher 2015], while the same trend was also confirmed by the UNCTAD investment report [UNCTAD 2013].

Researchers indicate which factors may affect the level of the participation of countries in GVCs. The most common determinants are [Amador, Cabral 2016; Kowalski et al. 2015; Kersan-Skabic 2019]:

- lowering the trade and investments costs,

- the share of trade covered by regional/preferential trade agreements,

- trade and investment liberalization,

- regional economic integration,

- FDI openness (FDI intensity, FDI inward stock),

- market size (GDP, GDP per capita, population),

- GDP growth rate,

- share of manufacturing in GDP,

- policy (tariffs, intellectual property protection, wages, profit tax rates),

- technological development.

As the researchers quoted above suggested, one of the most important factors was the size of an economy measured by the size of GDP. In their study of the countries for which data were available, they observed that larger countries were less involved in GVCs as opposed to smaller countries which had stronger participation in GVCs. In turn, van der Marel [Marel 2015] pointed out that the further away in the manufacturing chain the country is located from the end user, the stronger its upstream connection to GVCs. He also argued that countries with larger markets are located closer to the final stages of production and have weaker participation in GVCs. In contrast, smaller markets are more strongly involved in GVCs.

In addition, the results published in the investment report mentioned above [UNCTAD 2013] showed that in 2010 the participation of developed countries in GVCs was higher than that of developing countries (the GVC index stood at 59\% for the former group, and $52 \%$ for the latter).

The researchers quoted above argued that smaller countries tended to be more involved in GVCs, however they generally made their observations about all the countries together. No detailed calculations were included in any of the publications

${ }^{3}$ In particular, a lot of such work was created in relation to the regions of Southeast Asia [Choi 2015; Lee and Cheong 2015; Inomata 2014; Su 2014; Kwon and Ryou 2015]. 
that would estimate the relationship for developing and developed countries separately. The purpose of this article is therefore to verify whether there is a clear relationship between the size of an economy and participation in global value chains, taking into account the division into developed and developing countries.

\section{Methodological remarks}

In practice, the size of an economy can be measured in a number of ways: global GDP value or GDP per capita, the size of the population that has an impact on the volume of demand, etc. For the purposes of the article, global GDP value was used as the measure of the size of an economy. The relevant data were acquired from the UNCTAD database [UNCTADstat 2018].

Participation in GVCs was measured with the GVC indicator, which is the sum of two values: share of foreign value added embodied in exports of a researched country (upstream/backward participation in GVCs) and share of domestic value added embodied in foreign exports (downstream/forward participation in GVCs) ${ }^{4}$.

$$
\mathrm{GVC}=\mathrm{SFVA}+\mathrm{SDVA} \text {, }
$$

where: GVC - GVC index, SFVA - share of foreign value added embodied in exports (in \%), SDVA - share of domestic value added embodied in foreign exports (in \%).

The calculations used the data on upstream/backward participation and downstream/forward participation of global value chains from the Trade in Value Added (TiVA) database developed by the OECD and the WTO. On their basis, the global GVC index was calculated. The WIOD (World Input-Output Database) is an alternative source of relevant data, but the author decided to use the TiVA database because it covers a longer time range and contains data for more countries (63 countries) than the WIOD database (43 countries), which allowed for the separation of developed and developing countries.

Spearman's rank correlation coefficient was applied to assess the strength of the correlation $\left(\mathrm{R}_{\mathrm{s}}\right)^{5}$. The calculations were performed for a sample of 63 countries broken down into ${ }^{6}$ :

\footnotetext{
${ }^{4}$ Detailed information on the method for estimating the values used to determine these connections can be found in [Koopman et al. 2001].

${ }^{5}$ This coefficient can be used when a potential relationship is not linear in nature, which was shown by the charts illustrating the scale of participation in GVCs in terms of the GDP of the examined countries. The calculations were performed at the confidence level of $95 \%$, using STATISTICA software.

${ }^{6}$ The groups were based on the UN methodology. Two countries - Russia and Cambodia - were classified as developing economies, although the former is formally considered a transition economy, while the latter belongs to the least developed countries. In the examined period - from 2000 to 2015 - certain changes were introduced to the classification, but for the countries under examination the change involved moving new EU member states to developed economies. This was assumed for the entire period under examination [UN 2014].
} 
1) developed economies (37 countries): Australia, Austria, Belgium, Canada, the Czech Republic, Denmark, Estonia, Finland, France, Germany, Greece, Hungary, Iceland, Ireland, Italy, Japan, Latvia, Luxembourg, the Netherlands, New Zealand, Norway, Poland, Portugal, Slovakia, Slovenia, Spain, Sweden, Switzerland, the United Kingdom, the USA, Bulgaria, Croatia, Cyprus, Lithuania, Malta, Romania, Israel;

2) developing economies (26 countries): Chile, Korea, Mexico, Turkey, Argentina, Brazil, Brunei Darussalam, Cambodia, China, Colombia, Costa Rica, Hong Kong, India, Indonesia, Malaysia, Morocco, Peru, the Philippines, the Russian Federation, Saudi Arabia, Singapore, South Africa, Taiwan, Thailand, Tunisia, Vietnam.

\section{The relationship between the size of an economy and its participation in GVCs}

Table 1 presents data concerning the average level of GDP (in USD billion) in the examined countries.

Table 1. Average ${ }^{a}$ GDP (in USD billion)

\begin{tabular}{|c|c|c|c|}
\hline Years & Total & Developed economies & Developing economies \\
\hline 2005 & 200.6 & 211.6 & 185.4 \\
\hline 2006 & 221.8 & 232.1 & 207.6 \\
\hline 2007 & 262.9 & 269.9 & 237.3 \\
\hline 2008 & 283.8 & 283.8 & 265.4 \\
\hline 2009 & 251.5 & 251.5 & 257.8 \\
\hline 2010 & 287.0 & 247.8 & 314.1 \\
\hline 2011 & 298.0 & 273.7 & 353.1 \\
\hline 2012 & 314.4 & 256.7 & 383.0 \\
\hline 2013 & 323.3 & 270.0 & 373.4 \\
\hline 2014 & 338.1 & 272.6 & 364.5 \\
\hline 2015 & 299.1 & 290.6 & 313.4 \\
\hline
\end{tabular}

${ }^{a}$ The table shows the average level measured with the median.

Source: [UNCTADstat 2018], own calculations.

The average GDP in the entire sample increased over the relevant period from approximately USD 200 billion to almost USD 300 billion, while in developed countries the figure rose from less than USD 211 billion to USD 290 billion and in developing countries - from USD 185 billion to USD 313 billion. However, this level varied significantly between countries. The variation coefficient was on 
average $230 \%$ for the entire sample, $236 \%$ in the group of developed countries and $170 \%$ in the group of developing economies ${ }^{7}$.

Participation in GVCs in the entire sample remained at an average level of approximately $43-46 \%$ (Table 2). Developed countries showed a slightly higher average level of participation in global value chains than developing countries. In the former group, it amounted to $41.2-46.7 \%$ on average, whereas in the latter to 40.1-45.6\%. The variation in the level of participation in GVCs was definitely lower than in the case of GDP, since in the entire sample it stood at about $20 \%$, the same in the group of developed countries and in the group of developing countries ${ }^{8}$.

Table 2. Average ${ }^{a}$ participation of developed and developing economies in GVCs (in \%)

\begin{tabular}{|c|c|c|c|c|c|c|c|c|c|}
\hline \multirow[b]{2}{*}{ Years } & \multicolumn{3}{|c|}{ GVC index } & \multicolumn{3}{|c|}{$\begin{array}{l}\text { Downstream/forward } \\
\text { participation in GVCs }\end{array}$} & \multicolumn{3}{|c|}{$\begin{array}{l}\text { Upstream/backward } \\
\text { participation in GVCs }\end{array}$} \\
\hline & 要 & 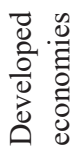 & 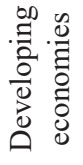 & 要 & 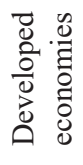 & 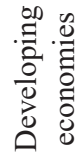 & 蹗 & 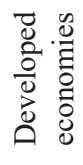 & 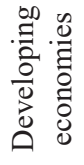 \\
\hline 2005 & 43.0 & 43.7 & 42.8 & 17.7 & 17.3 & 18.3 & 24.7 & 24.7 & 22.8 \\
\hline 2006 & 44.8 & 45.0 & 43.9 & 18.2 & 17.7 & 19.0 & 25.2 & 26.2 & 22.3 \\
\hline 2007 & 43.8 & 43.8 & 44.9 & 18.1 & 18.1 & 19.3 & 24.8 & 25.2 & 22.9 \\
\hline 2008 & 45.7 & 45.7 & 45.1 & 18.5 & 19.2 & 18.4 & 24.8 & 27.0 & 24.4 \\
\hline 2009 & 41.1 & 41.2 & 40.1 & 16.8 & 16.8 & 16.9 & 21.8 & 23.1 & 20.4 \\
\hline 2010 & 43.5 & 45.0 & 43.2 & 17.8 & 18.0 & 17.8 & 23.9 & 24.7 & 22.0 \\
\hline 2011 & 45.8 & 46.5 & 45.0 & 18.5 & 18.5 & 18.7 & 25.3 & 25.9 & 22.6 \\
\hline 2012 & 46.4 & 46.7 & 45.6 & 18.3 & 18.4 & 18.2 & 25.1 & 26.6 & 23.3 \\
\hline 2013 & 45.6 & 45.6 & 45.1 & 18.8 & 18.8 & 18.4 & 25.9 & 26.6 & 22.6 \\
\hline 2014 & 44.8 & 44.8 & 44.3 & 18.7 & 18.7 & 18.6 & 25.3 & 26.7 & 21.7 \\
\hline 2015 & 43.9 & 44.2 & 42.9 & 18.7 & 18.6 & 18.9 & 23.7 & 24.6 & 20.6 \\
\hline
\end{tabular}

a The table shows the average level measured with the median.

Source: [TiVA, ver. 2018], own calculations.

As the data in Table 2 show, both groups of countries had, on average, stronger upstream participation than downstream participation in global value chains. The average upstream participation in GVCs ranged from $21.8 \%$ to $25.9 \%$ for all 63 countries, while the developed countries had an average usually exceeding $24 \%$, compared with the developing countries which, on average, had GVC participation

\footnotetext{
${ }^{7}$ Own calculations based on the UNCTADstat data.

${ }^{8}$ Own calculations based on the data TiVA ver. 2016 and TiVA ver. 2018.
} 
lower than $24 \%$. On the other hand, the average downstream participation of all the countries was between $16.8 \%$ and $18.7 \%$. Developed economies showed a slightly higher involvement (17.3-19.4\%) than developing countries (17.8-19.3\%), but the difference was not significant as it amounted to only about 1 percentage point.

Table 3 presents the results of the analysis concerning the correlation coefficients showing the relationship between the GDP value and participation in GVCs of the examined countries, i.e. their upstream and downstream participation in GVCs and the overall GVC index. Calculations were performed for variables individually determined for all the examined countries, not for their average levels.

Table 3. Correlation between GDP and participation in GVCs

\begin{tabular}{|c|c|c|c|c|c|c|c|c|c|}
\hline \multirow[b]{2}{*}{ Years } & \multicolumn{3}{|c|}{ GVC index } & \multicolumn{3}{|c|}{$\begin{array}{l}\text { Downstream/forward } \\
\text { participation in GVCs }\end{array}$} & \multicolumn{3}{|c|}{$\begin{array}{l}\text { Upstream/backward } \\
\text { participation in GVCs }\end{array}$} \\
\hline & $\stackrel{\frac{\pi}{0}}{0}$ & 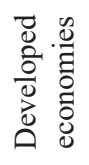 &  & 营 & 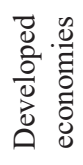 & 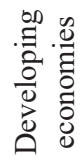 & 焉 & 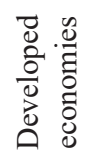 & 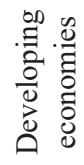 \\
\hline 2005 & -0.32 & -0.46 & -0.14 & 0.35 & 0.58 & 0.05 & -0.37 & -0.63 & -0.07 \\
\hline 2006 & $-\mathbf{0 . 3 0}$ & -0.43 & -0.08 & 0.35 & 0.58 & 0.06 & -0.37 & -0.61 & -0.09 \\
\hline 2007 & -0.29 & -0.39 & -0.16 & 0.34 & 0.56 & 0.08 & -0.35 & -0.52 & -0.17 \\
\hline 2008 & -0.34 & -0.45 & -0.16 & 0.33 & 0.51 & 0.06 & -0.37 & -0.54 & -0.16 \\
\hline 2009 & -0.34 & -0.45 & -0.19 & 0.32 & 0.51 & 0.06 & -0.37 & -0.57 & -0.15 \\
\hline 2010 & -0.34 & -0.49 & -0.16 & 0.32 & 0.52 & 0.03 & -0.37 & -0.56 & -0.12 \\
\hline 2011 & -0.33 & -0.46 & -0.16 & 0.34 & 0.59 & 0.04 & -0.37 & -0.55 & -0.14 \\
\hline 2012 & -0.38 & -0.45 & -0.25 & 0.36 & 0.64 & 0.00 & -0.42 & -0.58 & -0.16 \\
\hline 2013 & -0.41 & -0.46 & -0.31 & 0.36 & 0.65 & -0.04 & -0.42 & -0.58 & -0.19 \\
\hline 2014 & -0.41 & -0.45 & -0.33 & 0.37 & 0.64 & -0.05 & -0.41 & -0.57 & -0.15 \\
\hline 2015 & -0.40 & -0.45 & -0.29 & 0.32 & 0.59 & -0.06 & -0.40 & -0.58 & -0.06 \\
\hline
\end{tabular}

Figures in bold are statistically significant results at $p<0.05$

Source: [UNCTADstat, 2018; TiVA ver. 2018], own calculations.

The results revealed that all the examined countries experienced a moderate negative relationship between the GDP value and the GVC index in the period 2005-2015 . Spearman's correlation coefficient ranged from -0.29 to -0.41 . This implies that larger countries were less involved in GVCs than smaller economies and the coefficient of determination (Rs2) shows that the participation of the countries in GVCs depended on the size of their economy by about $8-17 \%$. However, a more detailed review of the results and the breakdown of the sample into two groups - developed and developing economies - revealed a very interesting picture. It 
turned out that such a relationship occurred only in the group of developed countries (the correlation coefficient ranged from -0.39 to -0.49 and all the results were statistically significant at $\mathrm{p}<0.05$, which means that participation in GVCs was determined by the size of an economy by $15-24 \%$ ), whereas the same link did not apply to developing countries.

A similar pattern concerned the relationship between the size of the economy and upward participation in GVCs. For the entire sample the correlation was negative with moderate strength (Rs from -0.35 to -0.42 ), but again this was attributable to a strong negative relationship between GDP and upward participation in GVCs for the developed countries (Rs from -0.52 to -0.63 , which means that their upward participation in GVCs was approximately $27-40 \%$ determined by the size of the economy), while in developing countries this was not observed.

The calculations also showed that a positive moderate relationship between downstream participation in GVCs and the level of GDP existed for all the examined countries. Again, this was the effect of the strong relationship between these variables in the group of developed countries. In this case it was a positive relationship (Rs from 0.50 to 0.65 ), which means that larger economies had stronger downstream participation in GVCs than smaller economies, and the coefficient of determination showed that the downstream participation of the developed countries in GVCs depended in approximately $26-42 \%$ on the size of an economy. With regard to developing countries, the results obtained did not show the existence of a relationship between the level of GDP and their downstream participation in GVCs.

\section{Conclusion}

The analysis established that in the examined group of 63 countries, participation in GVCs was related to the size of an economy. In the case of the overall GVC index and upstream participation in GVCs, it was found that the relationship was negative and weak, but it increased to moderate over the years, which confirmed the observations of other researchers. This means that larger economies were generally less involved in GVCs and their upstream participation was lower (which is equivalent to a smaller share of foreign value added in their exports) than smaller economies. Furthermore, a weak but positive relationship existed between GDP and downstream participation in GVCs. Accordingly, larger economies had stronger downstream participation than smaller countries.

It should be stressed, however, that the existing correlation was the effect of a strong relationship between the examined variables only in the group of developed countries. Therefore, it can be concluded that in developed countries the size of an economy was an important determinant of their participation in global value chains (larger economies were less involved in GVCs, had weaker upstream participation in GVCs, and stronger downstream participation in GVCs than smaller economies). However, the same pattern was not observed in the case of developing countries. 
The results showed that their participation in GVCs (both overall participation as well as upstream and downstream participation) was not related to the size of their economy.

In light of this, it may be interesting to investigate the reasons behind such a situation. Evidently, the size of GDP is an important determinant of participation in GVCs in developed countries, but other factors are decisive in the case of developing countries, hence the identification of these factors can be the subject of further research.

\section{References}

Amador J., Cabral S., 2016, Global value chains: a survey of drivers and measures, Journal of Economics Surveys, vol. 30(2), pp. 278-301. DOI: 10.1111/joes.12097.

Amador J., Cappariello R., Stehrer R., 2015, Global value chains: a view from the Euro Area, Asian Economic Journal, vol. 29(2), pp. 99-120. DOI: 10.1111/asej.12050.

Banga R., 2013, Measuring Value in Global Value Chains, "UNCTAD Background Paper”, No. RVC-8. http://unctad.org/en/PublicationsLibrary/ecidc2013misc1 bp8.pdf (30.12.2019).

Banga R., 2014, Linking Into Global Value Chains is not Sufficient: Do You Export Domestic Value Added Contents?, Journal of Economic Integration, vol. 29(2), pp. 267-297. DOI: 10.11130/ jei.2014.29.2.267.

Choi N., 2015, Global Value Chains and East Asian Trade in Value-Added, Asian Economic Papers, vol. 14(3), pp. 129-144. DOI: 10.1162/ASEP_a_00388.

Daudin G., Rifflart Ch., Schweisguth D., 2011, Who produces for whom in the world economy?, Canadian Journal of Economics, vol. 44(4), pp. 1403-1437. DOI: 10.1111/j.1540-5982.2011.01679.x.

Foster-McGregor N., Stehrer R., 2013, Value added content of trade: A comprehensive approach, Economic Letters, vol. 120(2), pp. 354-357. DOI: 10.1016/j.econlet.2013.05.003.

Grossman G.M., Helpman E., 2008, Outsourcing in a global economy, Review of Economic Studies, vol. 72(1), pp. 135-159. DOI: 10.1111/0034-6527.00327.

Grossman G., Rossi-Hansberg E., 2008, Trading tasks: a simple theory of offshoring, American Economic Review, vol. 98(5), pp. 1978-1997. DOI: 10.1257/aer.98.5.1978.

GTAP Database. https://www.gtap.agecon.purdue.edu/databases/default.asp (30.12.2019).

Hummels D., Ishii J., Yi K., 2001, The nature and growth of vertical specialization in world trade, Journal of International Economics, vol. 54, pp. 75-96. https://doi.org/10.1016/S0022-1996(00)00093-3.

Inomata S., 2014, Trade in Value Added: Concept, Development, and an East Asian Perspective, Conference on the Future of the World Trading System - Asian Perspectives in Geneva, 11-12 Mar 2013. [Online]. ADBI Series on Asian Economic Integration and Cooperation, pp. 48-70. https://www. adb.org/sites/default/files/publication/156306/adbi-wp451.pdf (30.12.2019).

Johnson R.C., Noguera G., 2012a, Accounting for Intermediates: Production Sharing and Trade in Value-Added, Journal of International Economic, vol. 86(2), pp. 224-236. DOI: 10.1016/j.jinteco.2011.10.003.

Johnson R.C., Noguera G., 2012b, Proximity and Production Fragmentation, American Economic Review, vol. 102(3), pp. 407-411. DOI: 10.1257/aer.102.3.407.

Johnson R., Bems R., Yi K.-M., 2011, Vertical linkages and the collapse of global trade, American Economic Review, Papers and Proceedings, vol. 101(13). DOI: 10.1257/aer.101.3.308.

Kersan-Skabic I., 2019, The drivers of global value chain (GVC) participation in EU member states, Economic Research - Ekonomska Istrazivanja vol. 32(1), pp. 1204-1218. DOI: 10.1080/1331677x.2019.1629978. 
Koopman R., Powers W., Wang Z., Wei S.-J., 2011, Give Credit Where Credit is Due: Tracing Value Added in Global Production Chains (October 26, 2011), HKIMR Working Paper, vol. 31. http:// dx.doi.org/10.2139/ssrn.1949669 (30.12.2019).

Kowalski P., Lopez Gonzalez J., Ragoussis A., Ugarte C., 2015, Participation of developing countries in global value chains: Implications for trade and trade-related policies, OECD Trade Policy Papers, Paris: OECD Publishing, http://dx.doi.org/10.1787/5js331fw0xxn-en (30.12.2019).

Kwon T., Ryou J. W., 2015, Global value chains of east asia: trade in value added and vertical specialization, Asian Economic Journal, vol. 29(2), pp. 121-143. DOI: 10.1111/asej.12051.

Lee C.-S., Cheong I., 2015, Value-added exports and the decomposition of exports in Korea trade, Journal of Korea Trade, vol. 19(4), pp. 43-61. WOS:000365933000003.

Los B., Timmer M.P., de Vries G., 2015, How global are global value chains? A new approach to measure international fragmentation, Journal of Regional Science, vol. 55(1), pp. 66-92. DOI: 10.1111 jors. 12121.

Marel E. van der, 2015, Positioning on the global value chain map: where do you want to be?, Journal of World Trade, vol. 49(6), pp. 915-949. WOS: 000369124100001.

$\mathrm{Ng}$ E., 2010, Production fragmentation and business-cycle comovement, Journal of International Economics, vol. 82(1), pp. 1-14. DOI: 10.1016/j.jinteco.2010.06.002.

Su Ch., 2014, The analysis of value-added Exports of China's high-tech manufactures, Advances in Social and Behavioral Sciences, vol. 6 (part 2), pp. 209-221. DOI: 10.5729/asbs.vol6.209.

TiVA Database ver. 2018. http://www.oecd.org/sti/ind/measuring-trade-in-value-added.htm (30.12. 2019).

UN, 2014, World Economic Situation and Prospects 2014, United Nations, New York. http://www. un.org/en/development/desa/publications/wesp2014-firstchapter.html (30.12.2019).

UNCTAD, 2013, World Investment Report 2013. Global value chains: investment and trade for development, Geneva.

UNCTADstat. http://unctadstat.unctad.org/EN/ (30.12.2019).

\section{UDZIAL W GVC A WIELKOŚĆ GOSPODARKI - PRZYPADEK KRAJÓW ROZWINIĘTYCH I ROZWIJAJĄCYCH SIE}

Streszczenie: Celem artykułu jest zbadanie zależności pomiędzy zaangażowaniem krajów rozwiniętych i rozwijających się w GVC a wielkością ich gospodarek (jako miarę wielkości gospodarki przyjęto wartość GDP). Uzyskane wyniki wykazały słabą, ale ujemną zależność pomiędzy wskaźnikiem GVC a wartością GDP, tzn. że większe kraje były mniej zaangażowane w GVC. Jednak oddzielenie w analizie krajów rozwiniętych od rozwijających się dało bardzo interesujące wyniki. Obliczenia pokazały, że zaangażowanie krajów rozwijających się w GVC było przeciętnie niewiele mniejsze niż krajów rozwiniętych, ale zależność pomiędzy badanymi zmiennymi była prawdziwa jedynie w odniesieniu do krajów rozwiniętych (współczynnik korelacji wskazywał na umiarkowaną zależność ujemną). Natomiast zaangażowanie krajów rozwijających się w GVC nie miało związku z wielkością ich gospodarek.

Słowa kluczowe: handel według wartości dodanej, globalizacja, handel międzynarodowy. 